\title{
Indice de materias
}

Prólogo a la edición espanola VII

Prefacio IX

Introducción $\quad$ XI

Primera parte: Descriptores agrupados según su significación 1

Estructura del conjunto 3

Descriptores 9

Segunda parte: Descriptores por orden alfabético 279 
